\title{
Innovation Trends in NAFTA Countries: an Econometric Analysis of Patent Applications
}

\author{
José Carlos Rodríguez', Mario Gómez²
}

\begin{abstract}
This paper analyzes innovation trends in North America Free Trade Agreement (NAFTA) countries by means of the number of patent applications during the period 1965 to 2008. Making use of patent data released by the World Intellectual Property Organization (WIPO) and the Network for Science and Technology Indicators (Red Iberoamericana de Ciencia y Tecnología, RICYT), we search for presence of multiple structural changes in the patent applications series in Canada, Mexico, and the United States. Such changes may suggest that firms' innovative activity has been modified in these countries (Mansfield, 1986). Accordingly, it would be expected that the new regulations implemented in these countries in the 1980s and 1990s have influenced their intellectual property regimes through the NAFTA and the TradeRelated Aspects of Intellectual Property Rights (TRIPS) agreement. Consequently, the question conducting this research is how the new dispositions affecting intellectual regimes in NAFTA countries have affected innovation activities in these countries. The results achieved in this research confirm the existence of multiple structural changes in the series of patent applications resulting from the new legislation implemented in these countries.
\end{abstract}

Keywords: NAFTA countries; intellectual property; patent applications; innovative activity; structural change.

\footnotetext{
' Corresponding author; Instituto de Investigaciones Económicas y Empresariales, (Economic and Business Research Institute), Universidad Michoacana de San Nicolás de Hidalgo, Edificio ININEE, Ciudad Universitaria, Morelia, Mich., Mexico, +52 (443) 3I6-5I 3 I, Ext. I0I. Email: jcrodriguez@umich.mx

${ }^{2}$ Instituto de Investigaciones Económicas y Empresariales, (Economic and Business Research Institute), Universidad Michoacana de San Nicolás de Hidalgo, Edificio ININEE, Ciudad Universitaria, Morelia, Mich., Mexico, +52 (443) 316-5I31, Ext. 104. Email: mgomez@umich.mx
} 


\section{Introduction}

This paper analyzes the innovation activity in North America countries by means of the number of patent applications filed by residents and non residents in Canada, Mexico, and the United States from 1965 to 2008. The hypothesis conducting this research is that the new dispositions implemented in the United States in the 1980s and 1990s in terms of intellectual property and technology transfer might affect its own intellectual property regime, as well as those regimes in Canada and Mexico through the North America Free Trade Agreement (NAFTA) and the Trade-Related Aspects of Intellectual Property Rights (TRIPS) agreement. The objective of this research is therefore to test for the possibility to find structural breaks in the series of patent applications filed by residents and non residents that result from changes in the intellectual property regimes in Canada, Mexico, and the United States. The possibility to find such changes might confirm that innovation activity in these countries has been modified allowing for more competitive activities across firms in these markets. However, the consequences of these changes had not been the same for all firms in these countries given that some of them would be more prepared for adopting new technologies, and thus for being more innovative and competitive.

However, testing for structural breaks may be performed through various econometric models. In the analysis of patent applications trends in North America countries, there are just a few studies that make use of econometric models in structural change analysis. Hall (2005), for example, analyzed patenting activity and innovative performance testing for structural breaks in the series of patent applications at industrial level in Untied States. Making use of the model suggested by Vogelsang (1997), Gómez and Rodríguez (2008) studied the case of North America Free Trade Agreement (NAFTA) and European Union (EU) countries (Canada, France, Germany, Mexico, Spain, United Kingdom, and the United States) testing for one break in the series of patents granted to residents and non residents in these countries. Similarly, Rodríguez and Gómez (2009) investigated the case of the NAFTA and EU countries testing for multiple structural changes in patents granted series in North America and Europe countries making use of the model proposed by Bai and Perron $(1998,2003)$ and the Bayesian Information Criterion (BIC).
However, the analysis developed in this research would allow us to find out how firms' innovation activity has change in North America countries after the adoption of the new regulations implemented there in terms of intellectual property and patenting activity during the 1980s and 1990s. To develop this research, we use the patent database released by the World Intellectual Property Organization (WIPO) and the Network for Science and Technology Indicators (Red Iberoamericana de Ciencia y Tecnología, RICYT) to test for presence of one or more structural changes in the series of patent applications in Canada, Mexico, and the United States. In this sense, it has been argued that the new regulations largely implemented in the United States during the 1980s and 1990s would have affected intellectual property regimes in Canada and Mexico through the North America Free Trade Agreement (NAFTA) and the Trade-Related Aspects of Intellectual Property Rights (TRIPS) agreement negotiated into the Uruguay Round (Scotchmer, 2004). Nevertheless, the new regulations affecting intellectual property regimes in these countries would have differently affected innovation activity across firms. Moreover, some scholars agree with the idea that such changes would modify patenting activity in favor of science-based industries (Hall 2005). On the other hand, other researchers mention that in North America countries, NAFTA and the TRIPS agreement have extended intellectual property rights beyond what is optimal, alienating intellectual property and patent protection just in favor of industry (Scotchmer, 2004). From the results achieved in this research, the trends observed in patent data in North American countries confirm the existence of multiple structural breaks that result from the new legislation implemented in these countries in the 1980s and 1990s. Moreover, evidence supports the idea that Canadian and Mexican firms are more willing to patent in the United States as a mechanism to ensure economic rents and establish market barriers to potential competitors. Actually, Canadian and Mexican firms ought to stimulate their own innovative capabilities to successfully compete in the marketplace in order to outweigh the increase in aggregate deadweight loss that arises when protection is extended across borders (Scotchmer, 2004). 
In addition to this introduction, this paper is organized as follows. Section 2 presents a review of the literature in relation to intellectual property, patent protection and innovative capabilities developments. Section 3 contains a description of the model and econometric methods applied in this paper to test for presence of one or more structural breaks in patent applications series in North America countries. Section 4 discuses the main results achieved in this research. Finally, Section 5 presents some conclusions.

\section{Literature Review}

Nowadays, with the emergence of the knowledge-based economy, current intellectual property systems ought to face new challenges. The tremendous changes observed in patent systems over the past two decades have moved into the same direction (Encaoua et al., 2006): expanding and strengthening the protection of innovations. However, since the 1970s, many other changes have been observed in relation to intellectual property regimes around the world. The passage of the Bayh-Dole Act in the United States in 1980, as well as other legislations related to intellectual property and technology transfer in the 1980s and 1990s would have influenced intellectual property regimes in other countries. Particularly, in the United States, this changes refers to the Patent and Trademark of 1980, the Trademark Clarification Act of 1984, the Federal Technology Transfer Act of 1986, and the National Competitiveness Technology Transfer Act of 1989 (Rodríguez, 2010). These dispositions allowed universities to hold their own patents drawn from federal research grants, supporting at the same time the creation of technology transfer offices (TTOs) in many universities and public research centers (Jaffe and Lerner, 200I; Siegel et al., 2004). However, the latest legal and administrative changes observed in the United States have affected its own intellectual property regime uncovering the need to adjust other intellectual property regimes in the world. The outcomes drawn from the new realm in terms of intellectual property and patenting activity in the United States opened up further opportunities to commercialize new knowledge through patents and licenses (Jaffe and Lerner, 200I; Siegel et al., 2004). In this sense, it is worth saying that the value of patents may increase considerably due to the monopolistic right awarded to the patent holder by the patent system (Deng, 2007). Nevertheless, national patent applications will continue to be driven by several factors (Peeters and van Pottelsberghe de la Potterie, 2006; De Rassenfosse and van Pottelsberghe de la Potterie, 2007): (I) firm size, (2) market power, (3) technological opportunity, (4) research efforts, and (5) intellectual property strategies adopted by the firm.

The effect of firm size on national patent applications derives from the Schumpeterian hypothesis suggesting that large firms are more innovative than small firms (Schumpeter, 1942). Large firms benefit from economies of scale and scope, spillovers and access to financial markets to financing risky innovation projects (Cohen and Levin, 1989). In some cases, small firms are more likely to patent to compensate for disadvantages in terms of market share and brand name (Brouwer and Kleinknecht, 1999). The relation established between market power and patent applications also derives from Schumpeter's hypothesis in that firms with a higher market power are more innovative than firms with weak market power (Schumpeter, 1942). Even if this factor has also been controversial, there is evidence of a positive impact of firm's market power on its innovation activity (Duguet and Kabla, 1998; Nielsen, 200I). In relation to technological opportunities, this variable is defined as the extent to which an industry relies on science-based research (Levin et al., 1987). In consequence, firms in high technology opportunity sectors are found to patent more than other firms (Brouwer and Kleinknecht, 1999). The relation established between research efforts and patent applications goes from R\&D to patents, as a process that affects firms' innovative performance. In this sense, the relationship between R\&D and patents can be seen as a virtuous cycle that requires further development costs in order to reach the market (Peeters and van Pottelsberghe de la Potterie, 2006). Finally, in relation to the intellectual property strategy adopted by firms, there are also many factors influencing their innovative capabilities, such as the relative importance of basic and applied research in total R\&D, the product or process orientation of innovation efforts, the extent to which $R \& D$ is jointly performed with other institutions, and the limitations and inefficiencies of the patent system (Peeters and van Pottelsberghe de la Potterie, 2006).

In this sense, it has been argued that the firms' patenting behavior might correlate with the type of innovation strategy pursued, the perceive barriers to the innovation process (internal, external, risk and cost-related barriers), and the limitations of the patent system they recognize (Peeters and van Pottelsberghe de la Potterie, 2006). Therefore, firms that perceive higher ineffectiveness of 
the patent system and higher cost of patenting would be less willing to patent nationally. Consequently, firms may evaluate patenting ineffectiveness, size of their domestic market, and the patenting cost associated to patenting nationally (or not) when defining their intellectual property strategy. As a result of these tendencies, the new realm characterizing intellectual property systems and policies in the world impose two types of obligations (Scotchmer, 2004): national treatment to foreign inventors and harmonized protection.

In the case of North America countries, these obligations have been acquired through NAFTA and the TRIPS agreement. However, patenting activity in Canada and Mexico has followed a different pathway than that in the United States. In Canada and Mexico, patenting activity is characterized to be idiosyncratic, responding to firms' specific needs to successfully compete in the marketplace. In fact, many Canadian and Mexican firms are now more willing to patent in the United States as a mechanism to ensure economic rents and to establish market barriers. In this sense, the TRIPS agreement has extended intellectual property rights beyond what is optimal as trade negotiations have been captured by industry (Scotchmer, 2004; Hall, 200I; Lanjouw and Cockburn, 200I). In this sense, Canadian and Mexican firms ought to stimulate their own innovative capabilities to outweigh the increase in aggregate deadweight loss that arises when protection is extended across borders (Scotchmer, 2004).

Particularly, in the case of Mexico, the patent regime in this country has undergone three sets of changes in the last years (Shadlen, 20I0): (I) the introduction of a new patent law in 1991, known as Industrial Property Law (Ley de Fomento y Protección de la Propiedad Industrial), (2) the establishment in the early 2000 s of some specific disposals regarding pharmaceutical patenting activity, and (3) the establishment of a set of measures to integrate patent policy with national innovation policy in the early 2000 s in order to establish closer ties between public science and private industry. On the other hand, the changes implemented during the 1970s, 1980s, and 1990s in Mexico aimed to make firms more competitive in this country: (I) Ley sobre el Registro de la Transferencia de Tecnología y el Uso y Explotación de Patentes y Marcas (1972), (2) Ley de Invenciones y Marcas (1976), (3) Ley de Invenciones y Marcas (reform) (1987), and (4) Ley de Fomento y Protección de la Propiedad Industrial (1991). Nevertheless, the new dispositions introduced throughout these decades in this country did not provide necessary incentives to the generation and commercialization of innovations, neither to foster the dissemination and use of new knowledge, nor to facilitate that local actors might have access and use new knowledge (Shadlen, 2010).

In the case of Canada, university R\&D spending and university-industry linkages have become extremely important. Accordingly, many Canadian universities are now involved in commercializing intellectual property and supporting innovative performance (Industry Canada, 2002). More recently, one of the main challenges of the Canadian government is to improve productivity and competitiveness across Canadian firms through innovation and use of science and technology. This goal would be achieved through three mechanisms (Industry Canada, 2007): (I) a strong private-sector commitment to science and technology, (2) strengthening its knowledge base, and (3) attracting, retaining and developing researchers. This policy may result in entrepreneurial, knowledge and people advantages.

\section{Model and Methods}

This study analyzes the possibility to find one or more structural breaks in the series of patent applications filed by residents and non residents in Canada, Mexico and the United States, resulting from the new dispositions implemented in terms of intellectual property in these countries. Structural change or structural instability has commonly been interpreted as a change in the regression parameters (Maddala and Kim, 1998). However, the structural or stability change hypothesis can be rejected when it is observed a change into a prevailing regime (Pulido, 200I). The existence and time location of a structural change can be econometrically tested through an autoregressive statistical time series dynamic model of order one $\operatorname{AR}(\mathrm{I})$ (Hansen, 200I), stated as follows:

$$
\begin{aligned}
& \mathrm{Y}_{\mathrm{t}}=\alpha+\rho \mathrm{Y}_{\mathrm{t}-1}+\mathrm{e}_{\mathrm{t}} \\
& \sum_{\mathrm{t}=1}^{\mathrm{n}} \mathrm{e}_{\mathrm{t}}^{2} /(\mathrm{n}-\mathrm{k})=\sigma^{2}
\end{aligned}
$$


In the first equation, $Y t$ represents a time series, and $Y t-1$ is the same time series but lagged one period in time. It is assumed that the error term et is not serially correlated. The second equation represents the formula for estimating the variance, where the numerator is the sum of squared errors and the denominator are the degrees of freedom (Gujarati, 2004). When one or all parameters of the model change at some point in the sample, we can say that a structural break has occurred. The possibility to find structural breaks in the series of patent applications filed by residents and non residents in North America countries results from the new regulatory changes implemented into the intellectual property regimes in these countries during the 1970s, 1980s, or 1990s. In fact, major changes in the intellectual property regimes in Canada, Mexico, and the United States were mostly implemented in the last two decades. To test for structural breaks, we used patent data from Canada, Mexico, and the United States released by WIPO and RICYT agencies. In this research, the patent data released by these offices was used as an indicator of innovative activity across firms in North America countries during the period of analysis.

\begin{tabular}{|ll|}
\hline Variable & \\
\hline PATCANR & Rate of growth of patent applications filed by residents in Canada \\
PATCANN & Rate of growth of patent applications filed by non residents in Canada \\
PATMEXR & Rate of growth of patent applications filed by residents in Mexico \\
PATMEXN & Rate of growth of patent applications filed by non residents in Mexico \\
PATUSAR & Rate of growth of patent applications filed by residents in the United \\
& States \\
PATUSAN & Rate of growth of patent applications filed by non residents in the United \\
& States \\
\hline
\end{tabular}

Table I Variable Definitions

Table I shows the definition of variables used in this model to test for one or more structural breaks in the series of patent applications filed by residents and non residents in Canada, Mexico, and the United Sates. The model was estimated using absolute values of the growth rates of the number of patent applications filed by residents and non residents in these countries. The model used to test for multiple structural breaks in the number of patent applications was specified following a multiple linear regression with $m$ breaks $(m+\mid$ regimes), where all coefficients are subject to change:

$$
\begin{aligned}
& \mathrm{y}_{\mathrm{t}}=\mathrm{z}_{\mathrm{i}} \delta_{\mathrm{j}}+\mathrm{u}_{\mathrm{t}} \quad\left(\mathrm{t}=\mathrm{T}_{\mathrm{j}-1}+1, \ldots, \mathrm{T}_{\mathrm{j}}\right) \\
& \text { for } \mathrm{j}=1, \ldots \mathrm{m}+1, \mathrm{~T}_{0} \text { and } \mathrm{T}_{\mathrm{m}+1}=\mathrm{T}
\end{aligned}
$$

In this case, $\mathrm{y}_{\mathrm{t}}$ is the observed dependent variable, $z_{t}(q x 1)$ is a covariance vector, $\quad \delta_{j}(j=1, \ldots, m+1)$ is the corresponding coefficients vector, and is a disturbance term. The parameter indicates the number of breaks. The break points $\left(T_{1}, \ldots, T_{m}\right)$ are explicitly treated as unknown. The estimation methods used in this research is based on the least square principles proposed by Bai and Perron (1998). For each $m$-partition $\left(\mathrm{T}_{1}, \ldots, \mathrm{T}_{\mathrm{m}}\right)$, denoted as $\left\{\mathrm{T}_{\mathrm{j}}\right\}$, the associated least squared estimated of $\delta_{\mathrm{j}}$ is obtained by minimizing the sum of the squared residuals $\sum_{\mathrm{i}=1}^{\mathrm{m}+1} \sum_{\mathrm{t}=\mathrm{T}_{\mathrm{i}-1+1}+1}^{\mathrm{T}_{1}}\left[\mathrm{y}_{\mathrm{t}}-\mathrm{z}_{\mathrm{t}} \delta_{\mathrm{t}}\right]^{2}$ constrained to $\delta_{\mathrm{i}} \neq \delta_{\mathrm{i}+1}(1 \leq \mathrm{i} \leq \mathrm{m})$. Let $\left.\dot{d}\left\{\mathrm{~T}_{\mathrm{j}}\right\}\right]$ to be the resulting estimations. Substituting it into the objective function and denoting the resulting sum of squared residuals as $\mathrm{S}_{\mathrm{T}}\left(\mathrm{TÖ}_{1}, \ldots, \mathrm{TO}_{\mathrm{m}}\right)$, the estimated break points $\left(\mathrm{TÖ}_{1}, \ldots, \mathrm{TÖ}_{\mathrm{m}}\right)$ are such that: 


$$
\left(\mathrm{TO}_{1}, \ldots, \mathrm{OO}_{\mathrm{m}}\right)=\operatorname{argmin}_{\mathrm{T}_{1}, \ldots, \mathrm{T}_{\mathrm{m}}} \mathrm{S}_{\mathrm{T}}\left(\mathrm{T}_{1}, \ldots, \mathrm{T}_{\mathrm{m}}\right)
$$

Where the minimization is taken over all partitions $\left(T_{1}, \ldots, T_{m}\right)$, such that $\mathrm{T}_{\mathrm{i}}-\mathrm{T}_{\mathrm{i}-1} \geq \mathrm{q}$. Thus, the break point estimators are global minimizes of the objective function. Finally, the regression parameter estimates are the associated least-squares at the estimated $m$ -partition $\left\{T_{j}\right\}$, i.e. $\ddot{\otimes}=\dot{\delta}\left\{\left\{T_{j}\right\}\right.$.

In this research, $A R(k)$ models were applied for each variable. The appropriate number of lags was determined using $\mathrm{Ng}$ and Perron (1995) methods, and estimating an $A R(k)$ process using the maximum value $k_{\max }$. If the latest lag was not significant, then the selection of $k$ was reduced by one. This process continued until the latest lag was significant or $\mathrm{k}=0$. In this case, 5 was taken as the maximum value of $k$ and the significance of the lags was evaluated using the critical value of $10 \%$ of the normal standard distribution. To determine the number of structural breaks, the Bayesian Information Criterion (BIC) was used (Yao, 1988). The number of estimated structural breaks $\hat{m}$ was determine by minimizing the above-mentioned information criterion give a fixed upper bound for $m, M=5$.

\section{Results}

The model estimated in this research was computed using RATS 6.0. From a general perspective, the results achieved in this research suggest that the main changes observed in the intellectual property regimes in North America during the 1980s and 1990s were important to explain changes in patenting activity across firms in these countries (Table 2 ). These results also confirm the idea that in the case of Canada and the United States, science and technology policies implemented in these countries during the 1980s and 1990s positively fostered firms' innovative capabilities and competitiveness. Particularly, in the case of the United States, patent applications series confirms the existence of structural breaks after the reforms implemented in this country since passing the Bayh-Dole Act in 1980, and with other reforms implemented during the 1980s and 1990s in this country. In this sense, it would be possible to say that the Bayh-Dole Act (1980), as well as those other reforms implemented in this country influenced firms' innovative capabilities and competitiveness. Moreover, in the United
States, structural breaks in patent applications series were observed in 1974, 1983, 1990, 1996 and 2002 in the case of residents (PATUSAR), and in the years 1969, 1983, 1992 and 1993 in the case of non residents (PATUSAN). However, these results also confirm that the new realm characterizing the intellectual property regime in this country positively influenced firms' innovative activity, as well as the desire of foreign inventors to patent in this market as a mechanism to ensure economic rents and to establish entry barriers. As it would be expected, the reforms implemented in the United States might influence intellectual property regimes in Canada and Mexico.

In the case of Canada and Mexico, the results confirm that the major changes observed in the series of patents applications filed by residents and non residents have followed a different pathway behavior. Particularly, in the case of Canada, structural breaks were observed in the years 1989 and 1994 in the case of patent applications filed by residents (PATCANR). In the same way, in this country, it is observed a more patenting activity in the case of non residents (PATCANN) during the years 1989, 1991, 1993, 1995 and 2000. However, these results suggest the idea that the new dispositions in relation to intellectual property and technology transfer in Canada have transformed its intellectual property regime to make it more attracting for patenting applications to non residents. Both residents and non residents reveal the importance of science and technology policy implemented in Canada during the years of 1990s searching to make Canadian firms more competitive in the marketplace. In this context, it is important to mention the role played by Canadian universities to performing a significant quantity of R\&D expenditure in order to develop innovations related to science-based industries. 


\begin{tabular}{|c|c|c|c|c|c|}
\hline \multicolumn{3}{|c|}{ Patent Applications by Residents } & \multicolumn{3}{|c|}{ Patent Applications by Non Residents } \\
\hline $\begin{array}{l}\text { Country } \\
\text { (Variable) }\end{array}$ & $\begin{array}{c}\text { Breaking } \\
\text { Y ear }\end{array}$ & $\mathrm{BIC}$ & $\begin{array}{c}\text { Country } \\
\text { (Variable) }\end{array}$ & $\begin{array}{c}\text { Breaking } \\
\text { Y ear }\end{array}$ & $\mathrm{BIC}$ \\
\hline $\begin{array}{l}\text { Canada } \\
\text { (PATCANR) }\end{array}$ & $\begin{array}{l}1989 \\
1994\end{array}$ & -4.142 & $\begin{array}{l}\text { Canada } \\
\text { (PATCANN) }\end{array}$ & $\begin{array}{l}1989 \\
1991 \\
1993 \\
1995 \\
2000\end{array}$ & -5.543 \\
\hline $\begin{array}{l}\text { Mexico } \\
\text { (PATMEXR) }\end{array}$ & $\begin{array}{l}1971 \\
1977 \\
1979 \\
1983\end{array}$ & -3.603 & $\begin{array}{l}\text { Mexico } \\
\text { (PATMEXN) }\end{array}$ & 1977 & -1.475 \\
\hline $\begin{array}{l}\text { United Sates } \\
\text { (PATUSAR) }\end{array}$ & $\begin{array}{l}1974 \\
1983 \\
1990 \\
1996 \\
2002\end{array}$ & -6.119 & $\begin{array}{l}\text { United Sates } \\
\text { (PATUSAN) }\end{array}$ & $\begin{array}{l}1969 \\
1983 \\
1992 \\
1993\end{array}$ & -5.807 \\
\hline
\end{tabular}

Table 2. Breaking Years in Patent Applications in NAFTA Countries

In the case of Mexico, structural breaks were observed in 197I, 1977, 1979 and 1983 in the case of patent applications filed by residents (PATMEXR), and 1977 in the case of patent applications filed by non residents (PATMEXN). These results may confirm that local inventors in Mexico had been influenced by the adherence of this country to some international agreements on intellectual property in the 1970s, as well as the introduction of new dispositions in terms of patenting practices. Actually, the new dispositions adopted in Mexico during the 1970s in relation to intellectual property and patenting activity revisited and reinforced the trends previously observed, namely increasing the cost of accessing knowledge without sparking increases in innovative activities (Shadlen, 2010). Furthermore, it would be possible to say that nowadays the problem with Mexico's new patent regime is that it is geared to promote innovation and the commercialization of new knowledge as if this country were much more developed than it is, given that two important features derived from these trends characterize its intellectual property regime (Shadlen, 20I0): (I) the patent system impose additional costs to consumers yielding higher prices with not benefits from increasing local innovations, and (2) inventors in this country continue to be more willing to patent in the United States as a mechanism to ensure economic rents.

\section{Conclusions}

This paper analyzed the possibility to find structural breaks in the series of patents applications filed by residents and non residents in North America countries. The objective was to get insight on the nature of these changes (structural breaks) resulting from the new realm characterizing intellectual property regimes in the world. Particularly, in the case of North America countries, it was argued that structural breaks in the number of patent applications series originated in the new dispositions in 
terms of intellectual property implemented in the United Sates. In this sense, the results confirmed the existence of structural breaks in the number of patent applications series in Canada and the United States resulted from the new dispositions in terms of intellectual property adopted in these countries during the 1980s and 1990s. In the case of Mexico, the results achieved in this research demonstrate that the reforms adopted in relation to intellectual property and patenting practices during the 1970s affected patent application trends in this country. Moreover, in México, other reforms adopted during the 1980s did not provide necessary incentives to commercialize innovations or support the dissemination of new knowledge. Actually, the new realm characterizing the intellectual property regime in Mexico strengthens the tendency already observed in relation that inventors would be more willing to patent in the United States as a mechanism to ensure economic rents and establish market barriers to potential competitors.

\section{Acknowledgments}

We are very grateful to Professor Bronwyn $\mathrm{H}$. Hall from the Graduate School of the University of California at Berkeley for her invaluable comments and advice, and Professor Gaétan de Rassenfosse from the European Centre for Advanced Research in Economics and Statistics (ECARES) of the Solvay Brussels School of Economics and Management at Université Libre de Bruxelles for his suggestions to improve this research. However, authors are responsible for any remaining errors.

\section{References}

ARUNDEL, A. (200I). The relative effectiveness of patents and secrecy for appropriation. Research Policy, 30(4), 61I-624.

BAI, J., Perron P. (1998). Estimating and testing linear models with multiple structural change. Econometrica, 66(II), 47-78.

BAI, J., Perron, P. (2003). Computation and analysis of multiple structural change models. Journal of Applied Econometrics, I8(I), I-22.

BROUWER, E., Kleinknecht, A. (1999). Innovative output and a firm propensity to patent: An exploration of CIS micro data. Research Policy, 28(6), 615-624.
COHEN, W. M., Levin, R. C. (1989). Empirical studies of innovation and market structure. In: Schmalensee, R., Willing, R. D. (Eds.), Handbook of Industrial Organization. North-Holland, Amsterdam.

COHEN, W. M., Nelson, R. R., Walsh, J. P. (2000). Protecting their intellectual assets: Appropriability conditions and why US manufacturing firms patent (or not). NBER Working Paper Series No. 7552.

DE RASSENFOSSE, G., van Pottelsberghe de la Potterie, B. (2007). Per un pugno di dollari: A first look at the price elasticity of patents. Oxford Review of Economic Policy, 238(4), 588-604.

DENG, Y. (2007). The effects of patent regime changes: A case study of the European patent office. International Journal of Industrial Organization, 25(I), I2I-I38.

DUGUET, E., Kabla, I. (1998). Appropriation strategy and the motivations to use the patent system: An econometric analysis at the firm level in French manufacturing. Annales d'économie et statistique, 49, 289-327.

ENCAOUA, D., Guellec, D., Martínez, C. (2006). Patent systems for encouraging innovation: Lessons from economic analysis. Research Policy, 35(9), 1423-1440.

GÓMEZ, M., Rodríguez, J. C. (2008). Innovative Activity in NAFTA and EU Countries: An Analysis of Structural Change in Patent Granted Trends. Proceedings of the Applied Econometrics Association. AEA, Tokyo.

GUJARATI, D. (2004). Econometría. McGraw-Hill, Mexico.

HALL, B. H. (200I). The Global Nature of Intellectual Property. Discussion Paper. Industry Canada, Ottawa.

HALL, B. H. (2005). Exploring the Patent Explosion. Journal of Technology Transfer, 30(2), 35-48.

HALL, B. H. (2007). Patents and patent policy. Oxford Review of Economic Policy, 23(4), 568-587.

HANSEN, B. (200I). The new econometrics of structural change: Dating breaks in U.S. labor Productivity. Journal of Economic Perspectives, 15(4), II7-I28. 
INDUSTRY CANADA. (2002). Achieving Excellence, Investing in People, Knowledge, and Opportunity. Industry Canada, Ottawa.

INDUSTRY CANADA. (2007). Mobilizing Science and Technology to Canada's Advantage. Industry Canada, Ottawa.

JAFFE, A. B., Lerner, J. (200I). Reinventing public R\&D: Patent policy and the commercialization of national laboratory technologies. The RAND Journal of Economics, 32(I), 167-198.

LANJOUW, J. O., Cockburn, I. M. (200I). New pills for poor people? Evidence after GATT. World Development, 29(2), 265-289.

LEVIN, R. C., Klerovick, A. K., Nelson, R. R., Winter, S. G. (1987). Appropriating the returns from industrial research and development. Brookings Papers on Economic Activity, 18(3), 783-831.

MADDALA, G.S., Kim,I.(1998).UnitRoot, Cointegrationand Structural Change. Cambridge University Press, Cambridge.

MANSFIELD, E. (1986). Patents and innovation: An empirical study. Management Science, 32(2), I73-18I.

NG, S., Perron, P. (1995). Unit root tests in ARMA models with data dependent methods for the selection of the truncation lag. Journal of the American Statistical Association, 90(429), 268-28I.

NIELSEN, A. O. (200I). Patenting, R\&D and market structure: Manufacturing firms in Denmark, Technology Forecast and Social Change, 66(I), 47-58.

PEETERS, C., van Pottelsberghe de la Potterie, B. (2006). Innovation strategy and the patenting behavior of firms. Journal of Evolutionary Economics, 16(I), 109-135.

PERRON, P. (1989). The great crash, the oil price shock, and the unit root hypothesis. Econometrica, 57(6), I36I-I40I.

PERRON, P. (1997). Further evidence on breaking trend functions in macroeconomics variables. Journal of Econometrics, 80(2), 355-385.

PULIDO, A. (200I). Modelos Econométricos. Ediciones Pirámide, Mexico.
RODRÍGUEZ, J. C. (20I0). University-Industry Technology Transfer in Canada: An Analysis of Stakeholders' Performance Using System Dynamics. Doctoral Dissertation, École de science de la gestion, UQÀM, Montreal.

RODRÍGUEZ, J. C., Gómez, M. (2009). Multiple Structural Changes in Patent Granted Series and Innovative Performance: The Case of NAFTA and EU Countries. Proceedings of the International Society for Professional Innovation Management. ISPIM, New York.

SCHUMPETER, J. A. (1942). Capitalism, Socialism and Democracy. Harper, New York.

SCOTCHMER, S. (2004). The political economy of intellectual property treaties. The Journal of Law, Economics \& Organization, 20(2), 4I5-437.

SCOTCHMER, S., Green, J. (1990). Novelty and disclosure in patent law. The RAND Journal of Economics, 20(I), I3I-I46.

SEN, A. (2003). On unit-root test when the alternative is a trend-break stationary process. Journal of Business and Economic Statistics, 2I(I), II-30.

SHADLEN, K. C. (2009). Harmonization, differentiation, and development: The case of intellectual property in the global trading system. In: Sacchetti, S., Sugden, R. (Eds.), Knowledge in the Development of Economics: Institutional Choices under Globalisation. Edward Elgar, Cheltenham and Northampton.

SHADLEN, K. C. (2010). The puzzling politics of patents and innovation policy in Mexico. Law and Business Review of the Americas, 16(4), 823-838.

SIEGEL, D. S., Waldman, D. A., Atwater, L. E., Link, A. N. (2004). Toward a model of the effective transfer of scientific knowledge from academicians to practitioners: Qualitative evidence from the commercialization of university technologies. Journal of Engineering and Technology Management, 2I(I/2), II5-I42.

VOGELSANG, T. (1997). Wald-type tests for detecting breaks in the trend function of a dynamic time series. Econometric Theory, I3(6), 818-849. 
J. Technol. Manag. Innov. 20II,Volume 6, Issue 3 